\title{
Description Of Depression Rates In Drug Case Inmates In Class II A Bulukumba Correctional Institution
}

\author{
Maghfira Ichlasul Amalia1, Nurlina ${ }^{2}$, Safruddin ${ }^{3 *}$ \\ Program Studi 1 Keperawatan Stikes Panrita Husada Bulukumba, Indonesia ${ }^{1}$ \\ Departemen Keperawatan Jiwa, Stikes Panrita Husada Bulukumba, Indonesia ${ }^{2,3}$ \\ *Corresponding Autor : Safaryahya@gmail.com
}

\begin{abstract}
Depression is an affective disorder, which is generally characterized by loss of interest or excitement, reduced energy so that it is easily tired and reduced activity. Depression can occur in anyone and at any period. Depression disorders have increased from year to year this is supported by data, the World Health Organization WHO which states depression is a common disease that occurs in the world, there are about 264 million people who suffer from depression that increases from year to year about 76-85\%. The goal is to identify the level of depression in drug inmates in The Correctional Institution Class II A Bulukumba Method used in this study is a descriptive design, which aims to get an overview of the level of depression in drug case inmates in The Correctional Institution Class II A Bulukumba. The affordable population in this study was inmates with drug cases, as many as 141 drug case inmates in the correctional institution Kls II A Bulukumba. The large sample in this study was 85 people. The researchers found results from 85 respondents (100\%) obtained results for the highest depressed proposri is mild depression with the number of 55 (64.7\%), while the lowest respondents who do not megalami depression with the number of $14(16.5 \%)$. The conclusion of this study is that there is a picture of the level of depression of drug case inmates in the correctional institution class II A Bulukumba. And researchers suggest that the results of this study can be used as a material to increase insights in the field of research as well as increase knowledge about depression and drug cases at the Correctional Institution Class II A Bulukumba.
\end{abstract}

Keywords: Depression Levels, Drug Cases

\section{INTRODUCTION}

Depression is an affective disorder, which is generally characterized by loss of interest or excitement, reduced energy resulting in fatigue and reduced activity. Depression can occur in anyone and at any time period(Rhapsody, 2014). Depression disorders have increased from year to year this is supported by data, the World Health Organization WHO which states depression is a common disease that occurs in the world, there are about 264 million people who suffer from depression that increases from year to year about 76-85\%. From data(Riskesdas, 2018), prevalence of depression 
in the population recorded in Indonesia as many as 706,689 people and for in south Sulawesi as many as 22,798 people who suffer from depression. The dominant age grouping of depressed people ranging from 15 years and above in Indonesia reached 6\% of the population in 33 provensi in Indonesia, the prevalence of mental disorders in Aceh, Jokjakarta, south Sulawesi, Bali and Central Java.

This is in accordance with the results of the general decree of correctional (Ditjenpas, 2020), which records that the number of prisoners in the province of South Sulawesi as many as 3,255 people, for the number of inmates as many as 7,937 , and the total number of inmates as many as 11,192 people. A person who becomes an inmate is the one who commits acts that are declared prohibited by the laws of indonesia and determined by legal process must be placed in the Pemasyarakan Institute so that it loses its independence. Loss of independence in inmates will lead to a decrease in dignity and self-esteem, so that depression arises and according to Adhayani Lubis, if a person enters the Penitentiary, he will realize that he will be in a state of unfettered, away from his parents, family and people he knows, and will enter a closed world, so that it tends to be depressed.

The results of the initial survey conducted in January 2020 at the correctional institution in Kls II A Bulukumba, obtained the number of inmates as many as 246 people with different cases, from the cases of drug users there are 141 people. From the results of interviews obtained from some inmates said to experience different depressions resulting from several factors including, the length of time fonis, family support, not getting physical freedom, thinking about a person's precepts about him, and thinking about how to socialize again after leaving the prison. Based on the results of a joint interview with doctors and nurses at the Correctional Institution Class II A Bulukumba said that inmates are a population that is vulnerable to the onset of various psychological problems. Psychological problems experienced by inmates as a result of life-changing patterns in prisons that are fraught with pressure and loss if not handled properly are vulnerable to increased depression.

Some previous studies conducted to look at the incidence of depression rates in inmates vary greatly from the results of research conducted by (Nursanti, 2014), inmates in Sleman's Class II B Prison which showed a prevalence of depression of 84.9\% 
and research conducted by (sari wati, 2014), using BDI showed a peresentase of depressed inmates in Class II A Banceuy Prison, West Java by 62.96\%. And this study is also supported by (Mukhlis, 2011), against 30 inmates with high depression scores at the Class II B Rembang Prison, Central Java revealed that the triggers of depression were caused by several factors accompanied by stressful events. Based on the above phenomenon, researchers are interested in conducting research on "Description of the incidence of depression in drug inmates in Class II Correctional Institution A Bulukumba".

\section{MATERIAL AND METHODS}

The design used in this study is descriptive design, which aims to get an overview of the level of depression in drug case inmates at the Class II Correctional Institution A Bulukumba. The affordable population in this study was inmates with drug cases, as many as 141 drug case inmates in the correctional institution Kls II A Bulukumba.The number of samples used in this study as many as 85 respondents in the correctional institution kls II A Bulukumba. Sampiling techniques used in this study using sitematic random sampling method is done to select samples from its population systematically. The goal is the same as simple random sampling, only the sample selection procedure is different. If in simple random sampling the selection of samples is done with a random table, then on sitematic random sampling is done by sorting population members, then selected a specific order systematically from the list of populations(darma, 2017).

\section{RESULTS}

Table 1. Frequency Distribution of Characteristics of Drug Case Respondents In Correctional Institution Class II A Bulukumba

\begin{tabular}{lcc}
\hline Caharacteristic & frekuensi $(F)$ & presentase \% \\
\hline Jenis kelamin & & \\
Laki-laki & 78 & 91.8 \\
Perempuan & 7 & 82 \\
\hline Usia & & \\
Remaja & 29 & 34.1 \\
Dewasa & 52 & 61.2 \\
Lansia & 4 & 4.7 \\
Pendidikan & & \\
Rendah & 84 & 98.8 \\
Tinggi & 1 & 1.2
\end{tabular}




\begin{tabular}{lll}
\hline Pekerjaan & & \\
Bekerja & 53 & 62.4 \\
Pelajar/mahasiswa & 15 & 17.6 \\
Tidak bekerja (IRT) & 17 & 20.0 \\
\hline \multicolumn{1}{c}{ Amount } & 85 & 100.0 \\
\hline
\end{tabular}

Based on table 1 showed that male gender reponden is more than female gender reponden, whereas male reponden as much as 78 respondents $91.8 \%$. Respondents who had an adult age were $61.2 \%$ more than adolescents and seniors.

Table 2. Distribution of depression frequency of drug case inmates at Class II Correctional Institution A Bulukumba

\begin{tabular}{|c|c|c|}
\hline Depression & frekuensi $(F)$ & Percentage \% \\
\hline Normal & 14 & $16.5 \%$ \\
\hline Mild depression & 55 & $64.7 \%$ \\
\hline Moderate depression & 16 & $18.8 \%$ \\
\hline Amount & 85 & 100.0 \\
\hline
\end{tabular}

Based on table 2 of 85 respondents (100\%) obtained results for the highest depressed proposri is mild depression with the number of 55 (64.7\%), while the lowest respondents who do not megalami depression with the number of 14 (16.5\%).

\section{DISCUSSION}

Based on the results of research conducted at the Correctional Institution Class II A Bulukumba. It can be noted that the description of the level of depression in drug case inmates varies from those who do not experience depression to moderate depression. For the highest proportion of depression was mild depression, while the lowest was respondents who did not experience depression. These findings are also supported by (Piter, 2011) depression is an emotional disorder that occurs in a person's life characterized by emotional, motivational, functional disorders of behavioral movements, and cognitive. A person with depression tends not to have hope or feelings of disintegration or excessive helplessness so cannot concentrate and make decisions, always tense and there is a desire to end life with self-help. Depression in inmates becomes part of psychological problems arising from stressors and a sense of loss of independence from living a different life to a free life outside prison(Safitri, 2019). 


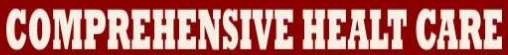

This study supports evidence from previous studies conducted by (Sinaga, 2020). Depression problems experienced by inmates during the criminal period are included in the category of mild to moderate. The occurrence of depression can be influenced by internal and external factors. Internal factors are age, level of education, marital status, and criminal duration, while the external factors are the existence of programs in prisons. There are similarities with the research conducted by (Wulandari, 2018), stated that, mild depression experienced by respondents is caused because the respondent has been able to adapt to the environment in prison, but still under pressure because the length of the sentence is still long, so still feel the loss of freedom in a long time. Depression is caused because the respondent gets a long sentence and just served a longer sentence, so the pressure felt is still considerable, the sense of loss of separation from family and friends, loss of freedom and pleasure for a long time makes the respondent suffer from moderate depression.

Researchers argue there are still drug convicts at the Class II A Bulukumba Correctional Institution who are depressed. This is because inmates who experience depressed mood, loss of freedom, and interest, evidenced by receiving bad information that causes pessimism and distrust, loss of pleasure. It can also be influenced by a variety of factors such as family support, social support, and pressure factors in life.

\section{CONCLUSIONS AND SUGGESTIONS}

The distribution of the number of respondents based on the level of depression of drug case inmates at the Class II Correctional Institution A Bulukumba is inmates who have more levels of depression compared to inmates who are not depressed. The distribution of the number of respondents based on drug case inmates at the Class II Correctional Institution A Bulukumba is inmates who have moderate depression as many as 17 respondents. Recommended For prisons, can add counseling programs that lead to a psychological approach and not just material. Skills programs and motivating activities also need to be provided so that later inmates are ready when dealing with a real social environment.

\section{REFERENCES}

Chiedu Eseadi, M. A. O., Shulamite E. Ogbuabor,And Amaka B. Ikechukwu-Ilomuanya 2017. Effects of Group-Focused Cognitive-Behavioral Coaching Program on Depressive 


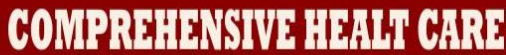

Symptoms in a Sample of Inmates in a Nigerian Prison. International Journal of Offender Therapy and Comparative Criminology.

DARMA, K. K. 2017. metodologi penelitian keperawatan, jakarta, Trans Info Media.

DITJENPAS 2020. sistem databes pemasyarakatan dektorat jendral pemasyarakatan.

HAWARI, D. 2013. manajemen stres,cemas,dan depresi, jakarta, fakultas kedokteran universitas indonesia FKUI.

WHO, W. H. O. 2019. internasional agency for research on depresion

WHO, W. H. O. 2019. internasional agency for research on depresion 